\title{
First report of Trichospilus diatraeae (Hymenoptera: Eulophidae) parasitizing pupae of Methona themisto (Lepidoptera: Nymphalidae)
}

\author{
Primer informe de Trichospilus diatraeae (Hymenoptera: Eulophidae) \\ que parasita pupas de Methona themisto (Lepidoptera: Nymphalidae)
}

\author{
Diego Arcanjo do Nascimento*1, Fábio Araújo dos Santos ${ }^{1}$, Vanessa Rafaela de Carvalho ${ }^{1}$, \\ Caroline Dias de Souza ${ }^{1}$ and Carlos Frederico Wilcken
}

\begin{abstract}
Urban afforestation is a practice used in urban centers. Of the plant species used, Brunfelsia pilosa and B. uniflora are used in most cities. The main pest for B. pilosa and B. uniflora is the lepidopteran Methona themisto which can feed on the leaves of the plant and cause its death. As a solution, biological control with parasitoid insects can be an alternative to chemical means. The present study aimed to investigate if $M$. themisto can be parasitized by Tichospilus diatraeae. Six pupae of M. themisto were offered to T. diatraeae and exposed to parasitism for 72 hours. The observed parasitism was $66 \%$ with $90 \%$ of the emergence of adult parasitoids. The parasitoid egg-to-adult life cycle was $18 \pm 1$ days and an average of $510 \pm 91.21$ insects emerged per pupa. Each parasitoid consumed an average of $1.13 \pm 0.16 \mathrm{mg}$ of pupal content to compete its cycle. The results record for the first time in the literature that $M$. themisto may be a host of $T$. diatraeae and consequently applied in biological control programs of this pest. Keywords: insects parasitoids, biological control, Forest entomology.
\end{abstract}

\section{RESUMEN}

La forestación urbana es una práctica utilizada en los centros urbanos. De las especies de plantas empleadas, Brunfelsia pilosa y B. uniflora se usan en la mayoría de las ciudades. La principal plaga para B. pilosa y B. uniflora es el lepidóptero Methona themisto, que puede alimentarse de las hojas de la planta y causar su muerte. Como solución, el control biológico con insectos parasitoides puede ser una alternativa a los medios químicos. Este estudio tuvo como objetivo investigar si M. themisto puede ser parasitado por T. diatraeae. Se ofrecieron seis pupas de M. themisto a T. diatraeae y se expusieron al parasitismo durante 72 horas. El parasitismo observado fue del $66 \%$ con el $90 \%$ de la aparición de parasitoides adultos. El ciclo de vida parasitoide de huevo a adulto fue de $18 \pm 1$ días y un promedio de $510 \pm 91.21$ insectos emergieron por pupa. Cada parasitoide consumió un promedio de $1.13 \pm 0.16 \mathrm{mg}$ de contenido de pupa para competir en su ciclo. Los resultados muestran por primera vez en la literatura que M. themisto puede ser un huésped de T. diatraeae y, en consecuencia, aplicarse en programas de control biológico de esta plaga.

Palabras clave: parasitoides de insectos, control biológico, Entomología forestal.

\section{Introduction}

Urban afforestation is understood as a system of green spaces in a city: squares and their vegetation, public gardens, urban parks, road afforestation and all forest cover in the cities. The Manacá (Brunfelsia pilosa and B. uniflora) is a tree of great importance in urban afforestation. It is native from the south and southeast of Brazil and has economic relevance as it contains medicinal, nutritional and ornamental properties (QuintansJúnior, 2008). Among the possible factors that can negatively affect the planting of manacá is the attack of pests, the main one being the manacá butterfly (Ruszczyk, 1999).

Methona themisto (Hübner, 1818) (Lepidoptera: Nymphalidae, Ithomiinae), known as the manacá butterfly, is listed as the main manacá pest

\footnotetext{
1 São Paulo State University (UNESP), Faculty of Agronomic Sciences (FCA), Fazenda Experimental Lageado, Botucatu, SP, Brasil.

* Correspondig author: diego.arcanjo@unesp.br.
} 
(Brunfelsia pilosa and B. uniflora). Insects of the order Lepidoptera can be controlled with natural enemies such as predators and parasitoids. Among the enemies, we highlight the pupae parasitoid Trichospilus diatraeae Cherian and Margabandhu (Hymenoptera: Eulophidae), of Asian origin and with gregarious behavior (Pastori et al., 2012a). This natural enemy has already been reported by parasitizing pupae of species from eight lepidopteran families, both in agriculture and in planted forests (Biezanko, 1960; Brown, 1992; Bennett et al., 1987; Oliveira et al. 2016; Silva et al., 2015; Zaché et al., 2012a; Zaché et al., 2012b).

This study aimed to evaluate parasitism and report, for the first time, $M$. themisto as an alternative host of $T$. diatraeae.

Adults of $T$. diatraeae were obtained from the creation of the Laboratory for Biological Control of Forest Pests at Universidade Estadual Paulista, Botucatu Campus, São Paulo, Brazil. The parasitoid was multiplied in pupae of Diatraea saccharalis Fabricius (Lepidoptera: Crambidae). Six pupae of $M$. thermisto are reared in laboratory were weighed and individualized in test tubes and offered to 10 females of T. diatraeae, in a 10: 1 ratio (parasitoid: host). Each pupa with 36 hours of metamorphosis, was considered a repetition (Figure 1).

After 72 hours, the parasitoid females were removed and the test tubes were kept at $25 \pm 2{ }^{\circ} \mathrm{C}$, $60 \%$ relative humidity and 12 hours photophase. The parameters: percentage of parasitism, number of emerged/retained parasitoids, consumption and the duration of the egg to adult cycle were evaluated. The parasitism by $T$. diatraeae was $66.66 \%$ in pupae of $M$. themisto on laboratory with an average of adult emergence of $90 \pm 0.92 \%$. The results when compared with the literature with other lepidopterans such as Eupalamides cyparissias (Fabricius), Brassolis sophorae L. (Lepidoptera: Nymphalidae) Opsiphanes invirae (Lepidoptera: Nymphalidae) the observed parasitism rate was $90 \%, 100 \%$ and $90 \%$ respectively (Ribeiro et al., 2013). We noticed a lower value in this study (66\%), however with a high emergence of parasitoids. In biological control programs, one of the factors observed is whether the host can be parasitized and whether it is possible to develop as many insects as possible.

The cycle of the parasitoid from egg to adult in pupae of $M$. themisto took an average of $18 \pm 1$ days. The life cicle it was longer than in Diatraea saccharalis (Lepidoptera: Crambidae), 17 days and shorter in Thyrinteina arnobia (Lepidoptera: Geometridae), 21 days and 20 days in Tenebrio molitor (Coleoptera: Tenebrionidae) (Chichera et al., 2012; Pastori et al., 2012b; Favero et al., 2013). From the parasitized pupae, a total of 2,041 adult parasitoids emerged, with an average of $510.25 \pm 91.21$ per repetition. The mean of emerged insects is considered satisfactory when compared with the results in other studies. Similar averages were obtained from $O$. invirae $(447.83 \pm 51.52)$ and B. sophorae $(669.00 \pm 89.62)$ (Ribeiro et al., 2013). The greater number of parasitoids emerging from pupae in an area with a lepidopteran outbreak promotes a greater chance of effective control, as it increases the chances of females seeking hosts to perform oviposition and consequently reduce the pest population.

Each individual consumed an average of $1.13 \pm 0.16 \mathrm{mg}$ of pupa of $M$. themisto to complete

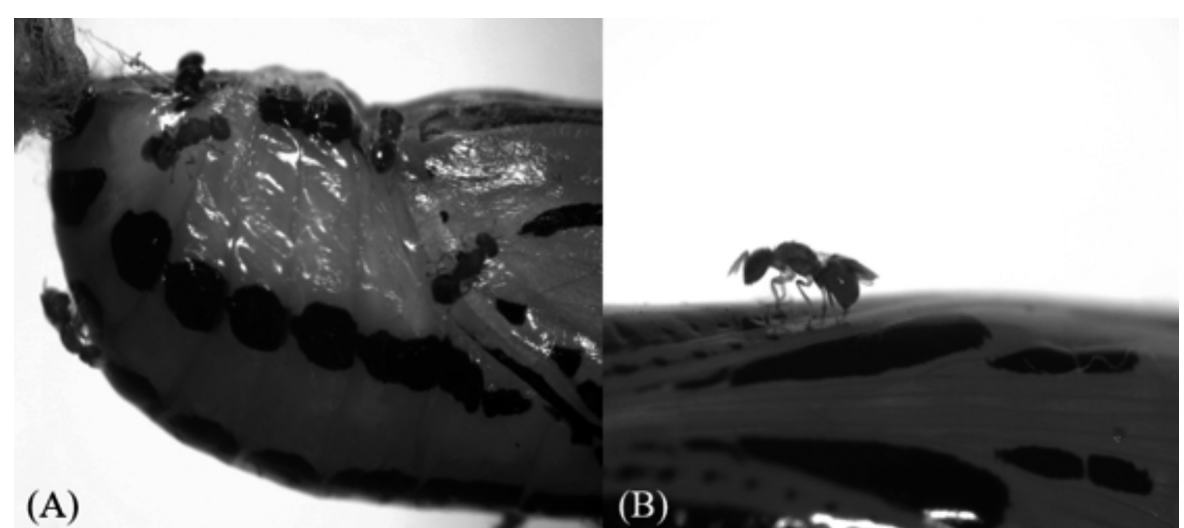

Figure 1. Trichospilus diatraeae (Hymenoptera: Eulophidae) adults parasitizing Metona thelmisto pupae on laboratory. 
the cycle (Figure 2). The ratio of host weight is directly related to the number of parasitoids emerging from a pupa. The larger the pupa, the more are the conditions for the development of insects. In other lepidopterans such as Opsiphanes invirae Hübner (Lepidoptera: Nymphalidae) the consumption was $3.35 \mathrm{mg}$ and in Brassolis sophorae L. (Lepidoptera: Nymphalidae) $3.43 \mathrm{mg}$ (Ribeiro et al., 2019). I n M. themisto, the parasitoid T. diatraeae needed fewer pupae consumption to complete its development.

Pupae that did not suffer parasitism were those that had the lowest weight. Parasitoid females look for the largest possible host, as it will possibly have the greatest quantity and quality of food resources for their offspring (Lin and Alves, 2003; Nofemela and Kfir, 2008). Non-parasitism of pupae 5 and 6 may be linked to the quality of the host. In this research, they were the ones that obtained less weight and inferior quality. The high number of adult parasitoids emerging per pupa illustrates that $M$. themisto may be an alternative host for T. diatraeae.

From the results obtained in this research, it is possible to guide future studies such as the effective use of $T$. diatraeae to control this and other urban pests of the order lepidoptera. It is an incipient study line that lacks basic studies like this, but it is of great environmental relevance and an alternative for the use of synthetic insecticides.

This work records for the first time the parasitism of Methona themisto by Trichospilus diatraeae.

\section{Acknowledgements}

Coordenação de aperfeiçoamento de Pessoal de Nível Superior - Brasil (CAPES) - Financing Code 001, Forest Protection Cooperative Program (PROTEF/ IPEF), Faculty of Agricultural Sciences (FCA-UNESP).

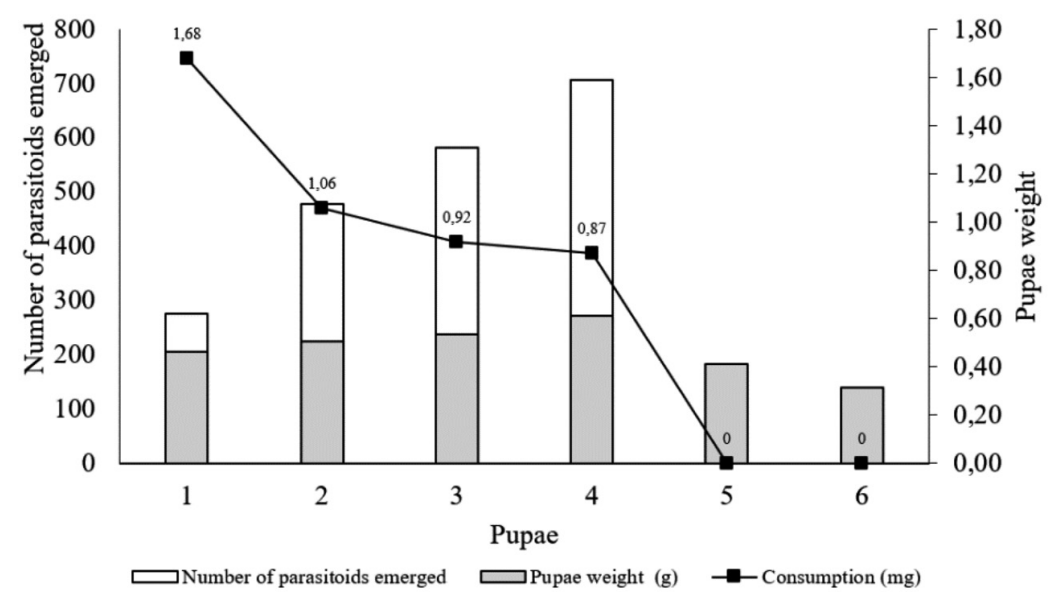

Figure 2. Number of adults of Trichospilus diatraeae (Hymenoptera: Eulophidae) emerged, comsumption and pupae weight of Metona Themisto (Lepidoptera: Nymphalidae).

\section{Literature Cited}

Bennett, F.D.; Glenn, H.; Yaseen, M.; Baranowski, R.M. 1987. Records of Trichospilus diatraeae, an Asian parasite (Hymenoptera: Eulophidae) from the Caribbean and Florida. The Florida Entomologist, 70 (1): 184-186.

Biezanko, C.M.

1960. Danaidae e Ithomiidae da zona Sudeste do Rio Grande do Sul. Arq. Entomol. Escola de Agronomia Eliseu Maciel (Ser. A), 3: 1-6.

Brown, Jr.

1992. Borboletas da Serra do Japi: diversidade, hábitats, recursos alimentares e variação temporal. In: Morellato L.P.C. (Ed.). História Natural da Serra do Japi: Ecologia e
Preservação de uma Área Florestal no Sudeste do Brasil Editora da Unicamp. Campinas, SP, Brasil. pp. 142-186. Chichera, R.A.; Pereira, F.F.; Kassab, O.; Barbosa, R.H.; Pastori, P.L.; Rossoni, C.

2012. Capacidade de busca e reprodução de Trichospilus diatraeae e Palmistichus elaeisis (Hymenoptera: Eulophidae) em pupas de Diatraea saccharalis (Lepidoptera: Crambidae). Interciência, 37 (11): 852-856. Favero, K.; Pereira, F.F.; Kassab, S.O.; Oliveira, H.N.; Costa, D.P.; Zanuncio, J.C.

2013. Biological characteristics of Trichospilus diatraeae (Hymenoptera: Eulophidae) progeny are influenced by the 
number of females exposed per pupa of Tenebrio molitor (Coleoptera: Tenebrionidae) pupae. Florida Entomologist, 96 (2): 583-589.

Lin, L.A.; Ives, A.R.

2003. The effect of parasitoid host-size preference on host population growth rates: an example of Aphidius colemani and Aphis glycines. Ecological Entomology, 28 (1): 542-550.

Nofemela, R.S.; Kfir, R.

2008. Diadegma mollipla parasitizing Plutella xylostella: host instar preference and suitability. Entomologia Experimentalis et Applicata, 126 (1): 9-17.

Oliveira, H.N.; Simonato, J.; Glaeser, D.F.; Pereira, F.F. 2016. Parasitism of Helicoverpa armigera pupae (Lepidoptera: Noctuidae) by Tetrastichus howardi and Trichospilus diatraeae (Hymenoptera: Eulophidae). Semina: Ciências Agrárias, 37 (1): 111-115.

Pastori, P.L.; Pereira, F.F.; Andrade, G.S.; Silva, R.O.; Zanuncio, J.C.; Pereira, A.I.A.

2012a. Reproduction of Trichospilus diatraeae (Hymenoptera: Eulophidae) in pupae of two lepidopterans defoliators of eucalypt. Revista Colombiana de Entomologia, 38 (1): 91-93.

Pastori, P.L.; Zanuncio, J.C.; Pereira, F.F.; Pratissoli, D.; Cecon, P.R.; Serrao, J.E.

2012b. Desenvolvimento e exigências térmicas de Trichospilus diatraeae Cherian \& Reproduction of Trichospilus diatraeae with Different Densities and Parasitism Periods 109 Margabandhu (Hymenoptera, Eulophidae) criado em pupas de Anticarsia gemmatalis (Hübner) (Lepidoptera, Noctui- dae). Rev. Bras. Bioc, 10 (1): 79-85.

Quintans-Júnior, L.J.; Almeida J.R.G.S.; Lima, J.T.; Nunes, X.P.; Siqueira, J. S.; Oliveira, L.E.G.; Almeida, R.N.; AthaydeFilho, P.F.; Barbosa-Filho, J.M.

2008. Plants with anticonvulsant properties - a review. Revista Brasileira de Farmacognosia, 18 (1): 798-819.
Ribeiro, R.C.; Lemos, W.D.P.; Castro, A.A.; Poderoso, J.C.; Serrão, J.E.; Zanuncio, J.C.

2013. Trichospilus diatraeae (Hymenoptera: Eulophidae): a potential biological control agent of lepidopteran pests of oil palm in the Brazilian Amazon. Florida Entomologist, 96 (2): 676-679.

Ribeiro, R.C.; Pikart, T.G.; Fouad, H.A.; Parreira, M.C.; Zanuncio, J.C.; Soares, M.A.; Castro V.R.

2019. Trichospilus diatraeae (Hymenoptera: Eulophidae): development and reproduction in Lepidoptera palm oil pests. Brazilian Journal of Biology, 79 (3): 377-382.

Ruszczyk, A.; Nascimento, E.S.

1999. Biologia dos adultos de Methona themisto (Hübner, 1818) (Lepidoptera, Nymphalidae, Ithomiinae) em praças públicas de Uberlândia, Minas Gerais, Brasil. Revista Brasileira de Biologia, 59 (4): 579-583.

Silva, I.M.; Zanuncio, T.V.; Pereira, F.F.; Wilcken, C.F.; Serrão, J.E.; Zanuncio. J.C.

2015. Reproduction of Trichospilus diatraeae (Hymenoptera: Eulophidae) in the pupae of Diaphania hyalinata (Lepidoptera: Crambidae) of various ages. The Florida Entomologist 98 (4): 1025-1029.

Zaché, B.; Zaché, R.R.D.C.; Souza, N.M.; Pogetto, M.D.; Wilcken, C.F.

2012a. Evaluation of Trichospilus diatraeae (Hymenoptera: Eulophidae) as parasitoid of the eucalyptus defoliator Eupseudosoma aberrans Schaus, 1905 (Lepidoptera: Arctiidae). Biocontrol Science and Technology, 22 (3): 363-366.

Zaché, B.; Wilcken, C.F.; Zache, R.R.C.; Souza, N.M.

2012b. Novo registro de Trichospilus diatraeae Cherian \& Margabandhu, 1942 (Hymenoptera: Eulophidae), como parasitóide de Spodoptera cosmioides Walker, 1858 (Lepidoptera: Noctuidae) no Brasil. Biota Neotropica, 12: 319-322. 